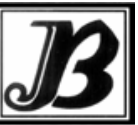

J. bio-sci. 16: 137-138, 2008

ISSN 1023-8654

http://www.banglajol.info/index.php/JBS/index

-Short Communication

\title{
POPULATION DYNAMICS OF MAIZE STEM BORER, CHILO PARTELLUS SWINHOE IN UPPER HIMALAYAS OF JAMMU REGION
}

\author{
Ishtiyaq Ahad*, R M Bhagat, Hafeez Ahmad and Mohammad Monobrullah
}

Sher-e-Kashmir University of Agricultural Sciences and Technology, Jammu-180001, India

Key words: Population, stem borer and natural enemies

In India maize crop is being attacked by about 139 species of insect pests with varying degree of damage. However, only about a dozen are quite serious (Sarup et al. 1987, Siddiqui and Marwaha 1993). Among them some important lepidopteran stem borers seriously limit potentially attainable maize yields by infesting the crop throughout its growth, from seedling stage to maturity. Seventeen species in two families (Pyralidae and Noctuidae) have been found to attack maize in various parts of Africa. However, Chilo partellus (Swinhoe), Chilo orichalcociliellus Strand, Busseola fusca Fuller, Sesamia calamistis Hampson, and Eldana saccharina Walker are of great importance. The yield losses caused by stem borers to maize vary widely in different regions and range from $25-40 \%$ according to the pest population density and phenological stage of the crop at infestation (Khan et al. 1997).

Among them maize stem borer, $C$. partellus is most dominant contributing $90-95$ per cent of the total damage in kharif season (Jalali and Singh 2002). Despite of, intensive work done in India on C. partellus yet, the work in Jammu region is lacking. As this pest is becoming a major problem in sub mountainous region of Jammu, yet distribution and intensity of infestation of this pest has not been studied therefore; it is imperative to study population patterns and natural enemies associated to this pest.

To achieve this objective, a multi directional light trap was operated from 1800 to 0600 hours daily. The collections were made weekly throughout the crop seasons of 2006 and 2007. Infestation of stem borer was determined by counting the total number of dead hearts and the leaf damage in each selected plot at weekly interval. Total number of healthy and infested plants was counted in each plot during each week and means of three selected locations were calculated.

It was evident that stem borer appeared in the light trap in $21^{\text {st }}$ week ( 6 adults), when the mean maximum and minimum temperature $\left(25.70\right.$ and $14.95^{\circ} \mathrm{C}$ ) with relative humidity $(63.50 \%)$ (Table 1). Maximum traps (47 adults / trap) were observed in $29^{\text {th }}$ week, when average maximum and minimum temperature (29.25 and $16.45^{\circ} \mathrm{C}$ ) with relative humidity $82.6 \%$. After $35^{\text {th }}$ standard week, number of adults decreased gradually to 3 moths/ trap in $41^{\text {th }}$ standard week when the maximum and minimum temperature $\left(23.34\right.$ and $\left.12.54^{\circ} \mathrm{C}\right)$ with relative humidity of $67.61 \%$. Thereafter no catch was observed. The adult population was positively correlated with weather parameters viz. relative humidity $(r=0.908, P<0.01)$ maximum $(r=0.501, P<0.05)$ and minimum $(r=0.484, P<0.05)$ temperatures.

Results clearly indicate that initially adult population tends to increase in summer months and decreases further till onset of winter season. Such results might be attributed due to hibernation of larvae into the stubbles and maize stalks. These findings are supported by Kumar (1984), Singh et al. (1985) and Kfir (1988) who found that overwintering larvae causing infestation hibernate into the stubble and stalk of maize.

\footnotetext{
* Corresponding author.
} 
Similarly Muhammad and Khawja (2002) reported 18.7 - 29.1\% hibernating larval population from higher reaches of Pak occupied Kashmir.

Table 1. Mean seasonal incidence of C. partellus during kharif 2006 and 2007.

\begin{tabular}{|c|c|c|c|c|c|c|}
\hline \multirow{3}{*}{$\begin{array}{l}\text { Standard } \\
\text { week }\end{array}$} & \multirow{3}{*}{$\begin{array}{l}\text { No. of adults } \\
\text { / trap }\end{array}$} & \multirow{3}{*}{$\begin{array}{c}\text { Mean infestation } \\
\text { (dead heart + leaf } \\
\text { infestation) }\end{array}$} & \multicolumn{4}{|c|}{ Meteorological observations } \\
\hline & & & \multicolumn{2}{|c|}{ Mean temperature $\left({ }^{\circ} \mathrm{C}\right)$} & \multirow{2}{*}{$\begin{array}{l}\text { Mean relative } \\
\text { humidity }(\%)\end{array}$} & \multirow{2}{*}{ Rainy days } \\
\hline & & & Maximum & Minimum & & \\
\hline 21 & 6.00 & 0.00 & 25.70 & 14.95 & 63.50 & 1.5 \\
\hline 22 & 7.00 & 0.00 & 26.30 & 15.65 & 62.15 & 1.0 \\
\hline 23 & 6.00 & 0.00 & 27.60 & 16.20 & 62.50 & 2.0 \\
\hline 24 & 7.00 & 0.33 & 31.10 & 17.70 & 64.90 & 1.0 \\
\hline 25 & 13.00 & 1.50 & 31.30 & 18.30 & 63.60 & 1.0 \\
\hline 26 & 21.50 & 3.66 & 33.10 & 19.40 & 63.00 & - \\
\hline 27 & 26.50 & 5.33 & 29.70 & 17.40 & 70.00 & 1.0 \\
\hline 28 & 36.50 & 8.66 & 31.40 & 17.65 & 72.00 & 1.0 \\
\hline 29 & 47.00 & 10.66 & 29.25 & 16.45 & 82.60 & 2.0 \\
\hline 30 & 46.00 & 11.66 & 32.15 & 19.10 & 77.50 & 1.0 \\
\hline 31 & 39.50 & 12.83 & 31.20 & 17.10 & 77.60 & 1.5 \\
\hline 32 & 38.00 & 13.83 & 28.30 & 16.70 & 81.05 & 1.0 \\
\hline 33 & 42.00 & 15.83 & 27.00 & 15.30 & 83.50 & 2.0 \\
\hline 34 & 30.50 & 17.16 & 25.80 & 15.30 & 72.50 & - \\
\hline 35 & 28.00 & 17.49 & 26.50 & 15.50 & 71.00 & 1.0 \\
\hline 36 & 16.50 & 18.83 & 26.40 & 14.95 & 69.90 & 1.0 \\
\hline 37 & 13.50 & 18.99 & 25.80 & 14.70 & 65.60 & - \\
\hline 38 & 12.50 & 20.66 & 25.45 & 13.50 & 64.10 & 1.0 \\
\hline 39 & 8.00 & 22.66 & 24.65 & 13.25 & 64.00 & 1.0 \\
\hline 40 & 7.00 & 22.83 & 23.83 & 13.05 & 63.35 & - \\
\hline 41 & 3.00 & 23.16 & 23.34 & 12.54 & 67.61 & - \\
\hline Mean & $21.66 \pm 3.27$ & $11.72 \pm 1.83$ & $27.90 \pm 0.63$ & $15.94 \pm 0.42$ & $69.62 \pm 1.54$ & $1.19 \pm 0.11$ \\
\hline
\end{tabular}

\section{References}

Kfir R (1988) Hybernation by the lepidopterous stalk borer Busseola fusca and Chilo partellus on grain sorghum. Entomol. Expt. Appl. 48:31-36

Khan Z R, Overholt W A and Hassana A (1997) Utilization of agricultural biodiversity for management of cereal stem borers and striga weed in maize-based cropping systems in Africa -a case study. http://www.cbd.int/doc/casestudies/agr/cs-agr-cereal-stemborers.pdf

Kumar R (1984) Insect Pest Control with special reference of African Agriculture, Edward Arnold, London. 298p.

Muhammad A and Khawaja F A (2002) Overwintering Population of Maize Stem Borer Chilo partellus (Swinhoe) at high altitudes of Kashmir. J. Biol. Sci. 2 (1): 1-4.

Sarup P, Siddiqui K H and Marwaha K K (1987) Trends in maize pest management research in India together with bibliography. J. Entomol. Res. 11(1): 19-68.

Siddiqui K H and Marwaha K K (1993) The Vistas of Maize Entomology in India. Kalyani Publishers, Ludhiana.

Singh U C, Mirsa U S, Dhamdhere S V and Dwivedi U S (1985) Carry over of stalk borer Chilo parteelus (Swin.) in off season in diff. Crops. J. Entomol. Res. 9: 170- 173. 